\title{
THE OCTO MOM MEETS CONSTITUTIONAL LAW: TESTING THE CONSTITUTIONALITY OF RESTRICTING FERTILITY TREATMENTS
}

\author{
Theresa Miller-Sporrer*
}

\section{INTRODUCTION}

On 26 January 2009, Nadya Suleman gave birth to eight children. ${ }^{1}$ The public outpouring of support quickly turned into widespread condemnation as more information about Ms. Suleman's multiple pregnancies and financial situation was released. ${ }^{2}$ Once the public learned not only that Ms. Suleman had six other children but also that all fourteen children had been conceived using in vitro fertilization, the public began to question both her judgment and the judgment of her doctor. ${ }^{3}$ The public apparently was willing to accept the birth if it was the non-deliberate product of a hormone-based fertility treatment but was less willing to accept the birth if it was the result of a deliberate choice on the part of Ms. Suleman and her physician.

Recent media attention on the Suleman Octuplets, "John and Kate Plus 8 ," and other similarly situated high order births (those in which a mother gives birth to triplets or more) has created the impression that high order births are increasingly common. In response, the mainstream media transformed a few high profile instances of high order births into an epidemic and has

\footnotetext{
* Theresa Miller-Sporrer is a third-year law student at the University of Pittsburgh and would like to thank the entire staff for their work on this note and every other piece in this issue. She received a B.S. in Anthropology/Archaeology from Mercyhurst College where her senior thesis was included as part of the final publication on the sites of Bab-ed Dhra and Numeria, sites believed to serve as the inspiration for Saddam and Gomorrah. Prior to starting law school, Ms. Miller-Sporrer worked as an archaeolgist.

1. Randal C. Archibold, Octuplets, 6 Siblings, and Many Questions, Whittier (CAL.) J., Feb. 3, 2009, available at $\mathrm{http} / / / \mathrm{www} . n y t i m e s . c o m / 2009 / 02 / 04 / \mathrm{us} / 04$ octuplets.html?ref=nadya_suleman.

2. Mike Celizic, "Everything I Do Revolves around My Children": Octuplets'Mom Explains Her Decision to Add Newest Eight into Her Life, MSNBC, Feb. 10, 2009, http://www.msnbc.msn.com/ $\mathrm{id} / 29130147$.

3. Molly Hennessy-Fiske, Expert Says Fertility Doctor Implanted Far Too Many Embryos in Nadya Suleman, L.A. TIMES, Oct. 19, 2010, at AA.1, http://articles.latimes.com/2010/oct/19/local/ la-me-octuplets-doctor-20101019.
} 
implied that the medical community is hotly debating the proper response to the problem. ${ }^{4}$ Responding to this perceived public debate and noting public interest in reducing the prevalence of high order births, several state legislatures, including California, Missouri and Georgia, are considering statutory limitations on the use of fertility treatments. ${ }^{5}$

The state and federal governments could take a number of possible statutory routes. The government could mandate selective reductions when multiple pregnancies result, eliminate or restrict access to hormone-based treatments, codify the existing medical guidelines, or take a more dramatic route: change existing insurance law to favor those treatments least likely to result in multiple pregnancies. Each of these options implicates significant constitutional concerns.

In setting into statutory stone the choices available to a woman and her doctor, the states may violate federal reproductive and substantive due process law. Reproduction has long been held a fundamental interest, interference with which will trigger the Equal Protection Clause's strict scrutiny test. ${ }^{6}$ Since the days of Skinner, reproduction has become a fundamental right under the Equal Protection Clause ${ }^{7}$ although, as will become apparent, this has resulted in a test that turns on undue burdens rather than on strict scrutiny. Although reproduction in the context of fundamental rights traditionally deals with preventing and terminating pregnancies, the logic of termination/prevention is equally applicable to the start of a pregnancy. Both stages of reproduction implicate the same underlying fundamental interest. Both require some medical intervention in order to achieve their ultimate goals. Government interference with either would therefore trigger the same level of scrutiny.

In the modern context, that level of scrutiny is the undue burden test laid out in Planned Parenthood v. Casey. ${ }^{8}$ Under Casey's model, ${ }^{9}$ restrictions are

4. Stephanie Saul, 21st Century Babies: The Gift of Life, and Its Price, N.Y. Times, Oct. 11, 2009, at A1, http://www.nytimes.com/2009/10/11/health/11 fertility.html?_r=1\&scp=1\&sq= the $\% 20$ gift $\% 20$ of $\% 20$ life $\% 20$ and $\% 20$ its $\% 20$ price\&st $=$ cse.

5. KRCG-TV, "Octo-Mom" Controversy Sparks Legal Action in Mo. (KRCG-TV television broadcast Mar. 6, 2009) http://www.connectmidmissouri.com/news/news_story.aspx?id=269472; Kimi Yoshino \& Jessica Garrison, Stricter Rules on Fertility Industry Debated, L.A. Times, Mar. 6, 2009, http://articles.latimes.com/2009/mar/06/nation/na-octuplets-laws6.

6. Skinner v. Oklahoma ex rel. Williamson, 316 U.S. 535, 541 (1942).

7. Griswold v. Connecticut, 381 U.S. 479, 485 (1965); Planned Parenthood v. Casey, 505 U.S. 833, 858 (1992).

8. Roe v. Wade, 410 U.S. 113 (1973); Casey, 505 U.S. at 876.

9. Casey, 505 U.S. at 876 . 
likely unconstitutional if they place a substantial and undue burden on a woman seeking pregnancy and that burden was not supported by a substantial and legitimate state interest. Mandated selective terminations would likely fail under this test, as would most restrictions on access to hormone-based therapies. In contrast, codification of existing medical guidelines and changes to existing insurance law would likely survive Casey.

This paper addresses which paths the government may take without violating the constitutional rights of potential parents. These possibilities are addressed from the perspective of a married couple seeking to have a child. The important issues presented by single women/men and by homosexual couples seeking to have children are, unfortunately, beyond the limited scope of this note.

The paper begins by giving an overview of relevant reproductive law. It then discusses various methods of Assisted Reproductive Technology (ARTs) and their side effects. The paper concludes by assessing both the constitutionality of ARTs and four possible government responses aimed at curbing their ill effects: (1) mandated selective terminations; (2) restricting or eliminating access to hormone-based ARTs; (3) codification of the medical communities standards and guidelines; (4) changes in insurance laws.

\section{Overview of Relevant Reproductive Law}

\section{A. Development of Reproduction as a Fundamental Interest}

Reproductive law developed under the auspices of the Equal Protection Clause as well as under substantive due process. Beginning with 1942's Skinner v. Oklahoma,${ }^{10}$ the Supreme Court began to consider the reproductive rights of individuals. Skinner found the sterilization of certain criminals but not others violated the Equal Protection Clause. Oklahoma justified the sterilization on the basis that "habitual criminals" (those who have been convicted of three felonies of moral turpitude) should not be allowed to procreate. ${ }^{11}$ The court found that this violated the Equal Protection Clause because the statute sterilized some classes of criminals but not others where the crimes were otherwise punished similarly. ${ }^{12}$

10. Skinner, 316 U.S. at 541.

11. Id.

12. Id. at 541 ("When the law lays an unequal hand on those who have committed intrinsically the same quality of offense and sterilizes one and not the other, it has made as invidious a discrimination as if it had selected a particular race or nationality for oppressive treatment."). 
Skinner ${ }^{13}$ ultimately led to the application of strict scrutiny to cases implicating fundamental interests. Under either a fundamental interest or a fundamental right-based approach, governmental interference with reproduction triggers a higher level of judicial scrutiny than does governmental interference in other areas. Skinner ${ }^{14}$ is perhaps more applicable to government action that limits access to ARTs because it specifically dealt with the government taking affirmative steps to prevent certain people from having children. Outside of Skinner, modern reproductive law focuses on the government preventing persons from preventing/terminating pregnancies.

Given that Skinner may be the more appropriate analytical model, the proper level of scrutiny would then fall under the Equal Protection Clause's strict scrutiny. In order to survive strict scrutiny, any measure taken by the government would have to be (1) supported by a compelling and legitimate government interest; (2) narrowly tailored; and (3) the least restrictive means available. ${ }^{15}$ Under this test, for reasons discussed infra, mandated selective terminations and elimination or severe restrictions of access to ARTs would both fail. Codification of medical community standards and changes in existing insurance laws would both pass this high level of scrutiny.

\section{B. Development of Reproduction as a Fundamental Right}

\section{Foundational Cases}

Since the days of Skinner, reproductive law has followed a different path. The vast majority of cases now deal with prevention/termination of pregnancies under the auspices of substantive due process. The right to reproduction as a fundamental right is rooted in both substantive due process and in the Equal Protection Clause. ${ }^{16}$ Under its modern incarnation, the right to substantive due process rests in the Fourteenth Amendment's guarantee that no person shall be deprived of his or her rights without due process of law. ${ }^{17}$

In Lochner, the Court found that the right to contract was protected under the Fourteenth Amendment and that this right had been violated. ${ }^{18}$ For the next fifty-years, Lochner was used to invalidate scores of legislation. The Lochner

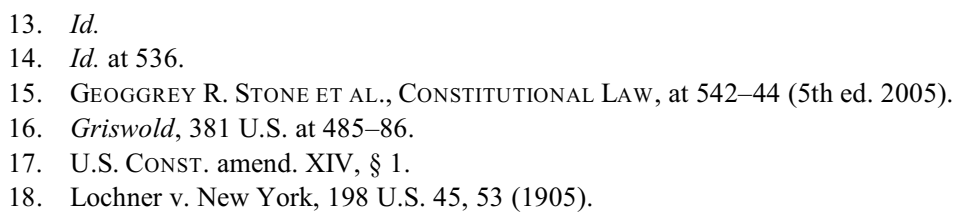


Era began to erode in Meyer v. Nebraska $(1923)^{19}$ and Pierce v. Society of Sisters (1925). ${ }^{20}$ In Meyer, the Supreme Court struck down a law banning schools from teaching foreign languages to children while in Pierce the Court invalidated a law requiring all children to attend public schools ${ }^{21}$ In each case, the Court protected the fundamental right of parents to rear their children (absent unprotected criminal activity). ${ }^{22}$ These holdings were carefully distinguished from Lochner on the basis of the right implicated. In Lochner, only the right to economic liberty was implicated whereas in Meyer and Pierce a much more fundamental interest - the right to rear children - was at stake. $^{23}$

Griswold v. Connecticut extended the fundamental right to rear children to the conception of those children. ${ }^{24}$ The plurality opinion found that irrespective of the route taken to get there, limiting access to birth control impermissibly intruded into the privacy of the marital bedroom. ${ }^{25}$ The majority found that although neither the Constitution nor the Bill of Rights expressly lists a right to privacy, the "specific guarantees in the Bill of Rights have penumbras, formed by emanations from those guarantees that help give them life and substance."26

Taken together, the First, Third, Fourth, and Ninth Amendments necessitate a penumbral right to privacy. ${ }^{27} \mathrm{Without}$ the right to privacy, those rights expressly enumerated in the Amendments would have no actual meaning. ${ }^{28}$ The Griswold majority found that the government's interests in regulating access to birth control were insufficient to warrant the intrusion into the protected rights of privacy and reproduction, which enforcing the regulation would require. ${ }^{29}$

The decision in Eisenstady v. Baird built on this foundation and unmoored Griswold from marriage. ${ }^{30}$ No longer did the right of access to birth control rest on the privacy of marital relations. ${ }^{31}$ This unmooring was

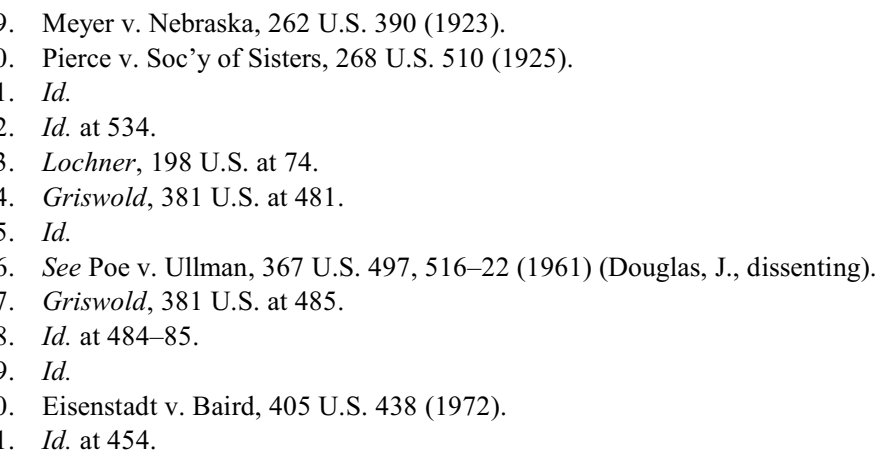


necessary because "[i]f the right of privacy means anything, it is the right of the individual, married or single, to be free from unwarranted governmental intrusion into matters so fundamentally affecting a person as the decision whether to bear or beget a child." ${ }^{32}$ Accordingly, the governmental interest was insufficiently compelling to warrant restricting access to birth control. ${ }^{33}$

\section{Roe v. Wade}

In light of the preceding cases, Roe v. Wade ${ }^{34}$ is not as shocking a conclusion as it appeared when it was first announced in 1973. In Roe, the Court held that a woman had the right to an abortion during the first trimester. ${ }^{35}$ The decision rested in the idea of bodily autonomy and the right of the individual to decide core values about family and reproduction. In order to determine the impact of these notions on the question of abortion, the Court extended and applied the Griswold concept of a right to privacy. ${ }^{36}$

In Roe, the Court noted that although the state maintains an interest in both potential life and maternal health, at some point the state's interest in maternal health becomes less compelling than its interest in the potential life. ${ }^{37}$ Thus, during the First Trimester, a woman may choose to have an abortion because at that point an abortion is safer than pregnancy and the fetus is not viable. $^{38}$

However, during the Second Trimester, access to abortion may be restricted as long as the restrictions consider the health of the mother. ${ }^{39}$ Once the fetus achieves viability, the state's interest in protecting the life of the fetus becomes compelling enough to warrant restrictions on abortion because there is more than a moral justification under the external harm principal. ${ }^{40} \mathrm{At}$ that stage, a mother's liberty interests lessen, but the compelling government interest is insufficient to warrant protection of the fetus at the expense of the mother's life. ${ }^{41}$

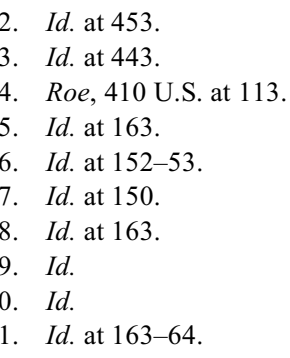


If, under Roe, the "right of privacy, whether it be founded in the Fourteenth Amendment's concept of personal liberty and restrictions upon state action, as we feel it is, or, ... in the Ninth Amendment's reservation of rights to the people, is broad enough to encompass a woman's decision whether or not to terminate her pregnancy[, ${ }^{142}$ then that broad right to privacy should also encompass a woman's decision as to what method of assisted reproduction to use when beginning her pregnancy.

\section{Subsequent Reproductive Rights Case Law}

In the years since Roe, reproductive rights law has changed in a number of ways. Beginning in 1992 with Planned Parenthood v. Casey ${ }^{43}$ and continuing through the ban on partial birth abortions, ${ }^{44}$ access to abortions has been curtailed. Irrespective of one's position on the merits of this retreat from unrestricted access to abortions, the fact remains that recent case law has altered the original stance adopted in Roe.

In 1992, Planned Parenthood v. Casey substantially changed the Roe framework but it did not un-ground Roe from a right to privacy. ${ }^{45}$ In Casey, Planned Parenthood challenged Pennsylvania's abortion law, claiming that the law unconstitutionally limited a woman's right to an abortion by imposing a 24-hour waiting period and spousal as well as parental consent. ${ }^{46}$ The Court agreed, but not as broadly as Planned Parenthood desired. ${ }^{47}$ The Court struck down the requirement of spousal notification but upheld the other portions of the law (namely a 24-hour waiting period, informed consent, and parental consent for minors). ${ }^{48}$

The Casey Court began by observing that although the majority of people in the country do not favor overruling Roe, a majority does support greater restrictions. ${ }^{49}$ Accordingly, the Court held that the right to an abortion actually means the right to stop the state from imposing an undue burden on a woman's decision to have an abortion..$^{50}$ The state maintains a legitimate interest in protecting fetal life from the onset and can justify restrictions on abortions

42. Id. at 153 .

43. Planned Parenthood v. Casey, 505 U.S. 837.

44. 18 U.S.C. $\$ 1531$ (2010).

45. Planned Parenthood v. Casey, 505 U.S. 837.

46. Id. at 844 .

47. Id. at 846 .

48. Id. at 878-79.

49. Id. at 860-61.

50. Id. at 878 . 
that stop short of being an undue burden. ${ }^{51}$ However, any restrictions must provide for medical emergencies and protect the health of the mother. ${ }^{52}$

Similarly, in the case of ARTs, the majority of Americans appear willing to have greater government control in the area. The public is troubled by high-order multiples and by the short- and long-term complications many of these children suffer. However, given the number of Americans who seek to use ARTs each year, the public would likely be unwilling to accept either a ban or severe restrictions on access to selected ARTs.

The Court thus substantially revised Roe v. Wade even as it ostensibly affirmed it. The Court replaced a strict scrutiny test with one based in 'undue burdens.' An undue burden, the Court wrote, was a "substantial obstacle placed in the path of a woman seeking an abortion of a nonviable fetus." ${ }^{53}$

The Court initially avoided an application of the Casey framework to partial birth abortion legislation. ${ }^{54}$ In Stenberg v. Carhart, the Court did not find it necessary to apply the Casey framework to the law because the law failed to adequately provide for an exception when the health of the mother is at risk. ${ }^{55}$ The Court invalidated the law on that basis without addressing the underlying issue of whether partial birth abortions should be available. ${ }^{56}$

Seven years later, the Court could not avoid the confrontation. In applying Casey, the Court in Carhart v. Gonzales significantly retreated from the large fraction analysis. ${ }^{57}$ In an opinion replete with references to maternal love and the regret women feel after an intact dilation and excavation (D\&E) partial birth abortion, the Court upheld the Federal Partial Birth Abortion Ban in spite of the arguably insufficient exception for preservation of the mother's health. ${ }^{58}$

The Court felt that intact D\&E is never medically necessary and that basic D\&E is always as safe as intact. ${ }^{59}$ This decision was reached without a consensus within the medical community concerning whether intact D\&E is ever medically necessary. Further, the testimony in favor of the ban generally came from non-experts. ${ }^{60}$ By finding that intact D\&E is never medically necessary, the Court summarily eliminated those women for whom intact

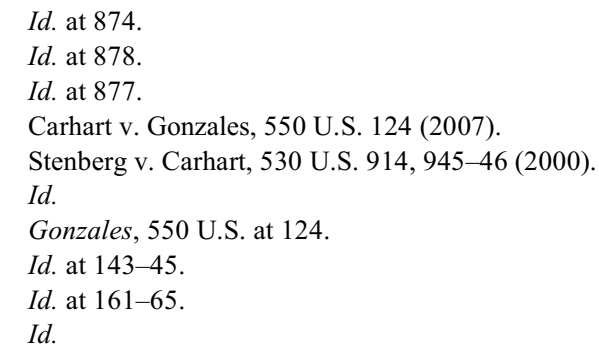


D\&E would be medically necessary or preferable from consideration. Thus, there was no large fraction affected by the law, making any assessment under Casey moot.

The danger of Gonzales is not its affirmation of a ban on intact D\&E. Rather, its danger lies in the justifications for that affirmation and its willingness to assume a paternalistic approach to intimate medical decisions. In assuming that a woman will regret her decision and using this assumption to validate its decision, the Court intrudes on her liberty and right to make decisions about her own life, whether or not she will later have regrets about her decision. The Court's willingness to make and use such assumptions has implications outside of abortion law. In the context of governmental intrusion into assisted reproduction, this willingness implies that the Court would be willing to find that women would regret having high order multiples and that this regret would validate (at least partially) government imposed limits on access to fertility treatments.

\section{Overview of Available Fertility Treatments and Associated Risks}

Fertility treatments have been available for nearly as long as abortion has been legal. Like abortions, determining which fertility treatment to use is a very patient-specific decision. ${ }^{61}$ Before beginning a course of treatment, the American Society for Assisted Reproduction mandates that couples receive counseling about both the medical treatments available and any possible side effects. ${ }^{62}$ During this consultation, a physician discusses the possibility of multiple births and the side effects inherent therein. ${ }^{63}$ Pre-term delivery with its associated risks of low birth weight and physical/mental developmental impairments, Cesarean sections, increased risk of pre-eclampsia and gestational diabetes are all discussed. ${ }^{64}$ The physician may also go over the financial and emotional burdens inherent in caring for multiple infants/young children, including an increased divorce rates for couples with multiple birth children. ${ }^{65}$

61. Telephone Interview with Melanie M. Ochalski, MD, Magee Women's Hospital (Oct. 22, 2009).

62. Am. Soc'y of Assisted Reprod. Guidelines, Fertility \& Sterility, Vol. 90, Supp. 3, Nov. 2008.

63. Telephone Interview with Melanie M. Ochalski, MD, supra note 61; Am. Soc'y for Reprod. Med., Patient Fact Sheet: Fertility Drugs \& the Risk of Multiple Births, 2008; Am. Soc'y for Reprod Med., Multiple Pregnancy \& Birth: Twins, Triplets, \& Higher Order Multiples, A Guide for Patients, (2004); Am. Soc'y for Reprod. Med., Patient's Fact Sheet: Challenges of Parenting Multiples (2003).

64. Id.

65. Id. 
The goal of this discussion is for the woman or couple to make an informed decision about the course of treatment. ${ }^{66}$ However, "at the end of the day these couples are so desperate to have a baby that they can't even really think about the physical and emotional side effects. So how good is their consent?" ${ }^{\circ 7}$ Ultimately, desire and bias aside, these women and couples have been made fully aware of the risks they face. They accept the consequences of their actions and choose, under the consultation of their doctors, a course of treatment that works best for them as individuals.

\section{Fertility Treatments}

\section{Interuterine Insemination}

As the name implies, interuterine insemination involves the fertilization of an egg or eggs within the uterus. ${ }^{68}$ A woman undergoes one of several hormone therapies to stimulate the maturation of egg follicles. ${ }^{69}$ In the United States, doctors typically halt hormone therapy when four egg follicles reach maturity, although in Europe doctors typically halt at three..$^{70}$

At this point, either the woman and her partner engage in timed intercourse or the woman is injected with a cleaned sperm sample. ${ }^{71} \mathrm{~A}$ successful pregnancy occurs approximately $15 \%$ after a single cycle but increases to $50 \%$ after three. ${ }^{72}$ If the process creates more than one or two viable embryos, which it does $23-30 \%$ of the time, the woman is given the option of selective reduction. ${ }^{73}$ Many women opt for the procedure and give birth to either a singleton or twins. ${ }^{74}$

Hormone therapy coupled with interuterine insemination is more likely to result in high order multiples than is in vitro fertilization (discussed in greater detail infra).$^{75}$ Doctors generally prefer to use in vitro fertilization

66. Am. Soc'y for Reprod. Med., Assisted Reproductive Technologies: A Guide for Patients (2008), http://www.asrm.org/uploadedFiles/ASRM_Content/Resources/Patient_Resources/Fact_Sheets_and_ Info_Booklets/ART.pdf.

67. Telephone Interview with Melanie M. Ochalski, MD, supra note 61.

68. $I d$.

69. Id.

70. Fertility Plus, http://www.fertilityplus.org/faq/iui.html (last visited Dec. 19, 2009).

71. Id. at 72 .

72. $I d$.

73. Id.

74. Am. Soc'y for Reprod. Med., Assisted Reproductive Technologies: A Guide for Patients, supra note 66 .

75. Am. Soc’y for Reprod. Med., Multiple Pregnancy and Birth: Twins, Triplets, \& Higher Order 
because the process gives them greater control over the outcomes, but interuterine insemination is often a better, or the only viable, option. ${ }^{76}$ Some couples may have religious objections to fertilization taking place outside of the mother while others may be faced with significant financial limitations. ${ }^{77}$ Financial concerns are often a primary reason for opting for hormone therapy coupled with interuterine injection. ${ }^{78}$ Each cycle costs between $\$ 200-300$ without hormones and around \$5,000-6,000 with hormone treatment. ${ }^{79}$ Although this is high, the figure is far lower than the $\$ 9,000+$ per cycle cost of in vitro fertilization. ${ }^{80}$

\section{In Vitro Fertilization}

Interuterine insemination works well for many women but not for all. It is ineffective for women who suffer from tubal blockage or severe tubal damage, ovarian failure (menopause), and advanced stages of endometriosis. ${ }^{81}$ It is also ineffective if the male suffers from severe male factor infertility ${ }^{82}$ In these cases, doctors have no option but must resort to in vitro fertilization. ${ }^{83}$

In vitro fertilization is similar to inter-uterine insemination in that it begins with giving the mother hormones to stimulate the maturation of egg follicles. ${ }^{84}$ The eggs are then harvested from the woman and combined with a cleaned sperm sample. ${ }^{85}$ From here, three different methods of in vitro fertilization emerge: Gamete Intrafallopian Tube Transfer (GIFT), Zygote Intrafallopian Transfer (ZIFT), and traditional. ${ }^{86}$ After one to six days of traditional in vitro fertilization, fertilized eggs are either implanted in the woman or frozen. ${ }^{87}$ The American Society for Reproductive Medicine

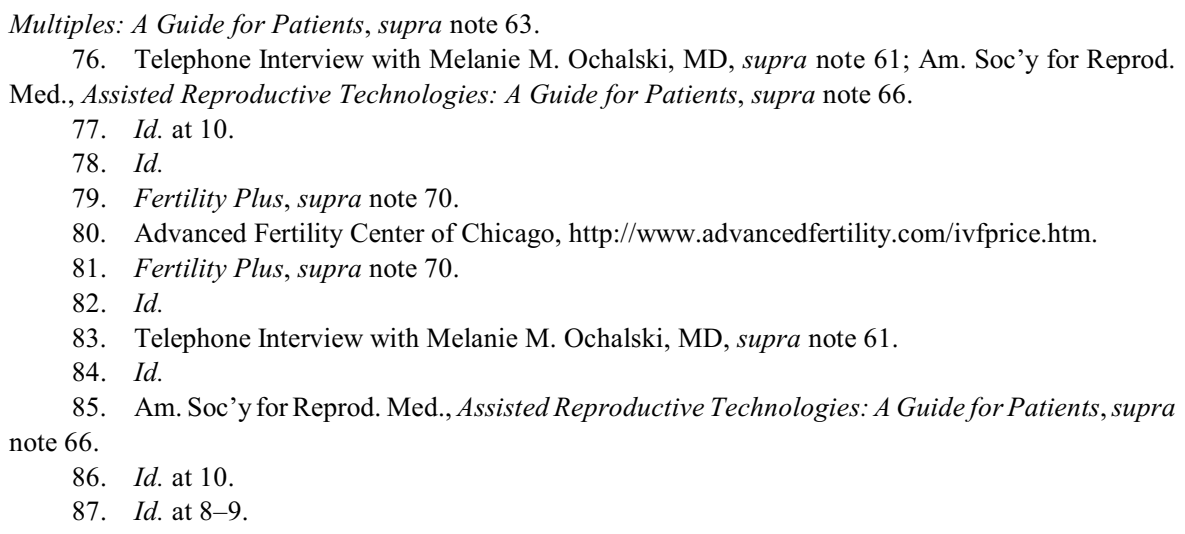


(ASRM) recommends implanting no more than three embryos at a time. ${ }^{88}$ As with interuterine insemination, if multiple embryos attach and become viable, the mother may choose selective termination. ${ }^{89}$ Most women opt for the selective termination procedure. ${ }^{90}$ Unlike interuterine insemination, selective termination is rarely necessary given that few doctors will implant more than one or two embryos per cycle. ${ }^{91}$

Gamete Intrafallopian Tube Transfer (GIFT) is a 'hybrid' of interuterine insemination and traditional in vitro fertilization..$^{92}$ As with traditional in vitro fertilization, a woman is given hormones to stimulate the production of eggs, and the mature eggs are removed from the woman. ${ }^{93}$ The eggs are then combined with mobile sperm, and the mixture is immediately injected into the woman's fallopian tubes. ${ }^{94}$ As with interuterine insemination, this procedure runs a higher risk of producing multiples. ${ }^{95}$ GIFT is recommended for women who did not succeed with interuterine insemination but who do not have severe fertility problems. ${ }^{96}$

If interuterine insemination and GIFT both fail to produce a successful pregnancy, a doctor may recommend that a patient try a Zygote Intrafallopian Transfer (ZIFT). ${ }^{97}$ ZIFT follows the same procedures as GIFT and traditional in vitro up to the point of fertilization. ${ }^{98}$ With ZIFT, the egg is fertilized outside of the woman and then implanted. Unlike traditional in vitro, the embryo is implanted into the fallopian tubes. ${ }^{99}$

The success rate for in vitro fertilization is much higher than interuterine insemination. It results in live birth in $22 \%$ of cases after three cycles, and as high as $72 \%$ after six. ${ }^{100}$ However, the increased success rate comes at a high

\footnotetext{
88. Id. at 9 .

89. Id.

90. Id.; Telephone Interview with Melanie M. Ochalski, MD, supra note 61.

91. Telephone Interview with Melanie M. Ochalski, MD, supra note 61.

92. Am. Soc'y for Reprod. Med., Assisted Reproductive Technologies: A Guide for Patients, supra note 66 .

93. Id.

94. Id.

95. Id. at 13 .

96. Gamete Intrafallopian Transfer: GIFT, American Pregnancy Ass'n, http:// www.americanpregnancy.org/infertility/gift.html (last visited Dec. 19, 2009).

97. Zygote Intrafallopian Transfer: ZIFT, American Pregnancy Ass'n, http:// www.americanpregnancy.org/infertility/zift.html (last visited Dec. 19, 2009).

98. American Pregnancy Ass'n, supra note 96.

99. Telephone Interview with Melanie M. Ochalski, MD, supra note 61.

100. Robynne Boyd, New Estimates for IVF Live Birth Rates, http://www.webmd.com/infertilityand-reproduction/news/20090114/new-estimates-for-ivf-live-birth-rates.
} 
price. Each round of implantation costs an average of $\$ 12,000$-plus. ${ }^{101}$ Most insurance plans will only cover a single cycle, and given that there is a lower chance of initial success, this insurance shortcoming pushes many couples toward interuterine insemination. ${ }^{102}$

\section{Side Effects of Multiple Births}

Premature delivery is one of the main side effects of high order multiple birth. All of the other "side effects" are actually caused by preterm delivery. Twins carry a $60 \%$ chance of pre-term delivery. ${ }^{103} \mathrm{With}$ triplets, the likelihood of a preterm delivery increases to over $90 \% .{ }^{104}$ Of the 137,085 twins born in 2006, 23,284 were conceived using in vitro fertilization. ${ }^{105}$ The Bureau of Vital Statistics found that "less than 20 percent of all triplets/+ born between 1997-2003 are estimated to have been naturally conceived." ${ }^{106}$ Nationwide, $12.7 \%$ of births occur prematurely, and the use of fertility treatments has increased this figure by $36 \%$ over the past twenty-five years. ${ }^{107}$

Preterm infants are also more likely to have a low birth weight compared to full-term infants. ${ }^{108}$ Low birth weight is defined as below 5.5 pounds. ${ }^{109}$ These children "are at increased risk of health problems in the newborn period as well as lasting disabilities, such as mental retardation, cerebral palsy, and vision and hearing loss." 110

The high rate of premature birth and accompanying low birth weights among infants conceived using ART is a contributing factor to the United States' high infant mortality rate, albeit a very minor one given the number of births. ${ }^{111}$ The United States ranks thirty-third in infant mortality, with nations such as Cuba ranking above us. ${ }^{12}$ Understandably, the federal government

101. e-Medicine Health, In Vitro Fertilization, www.emedicinehealth.com/in_vitro_fertilization/ page2_em.htm (last visited Oct. 10, 2010).

102. $I d$.

103. Joyce A. Martin et al., National Vital Statistics Reports, vol. 57. No. 7 (Jan. 7, 2009), at 20, http://www.cdc.gov/nchs/data/nvsr/nvsr57/nvsr57_07.pdf.

104. National Vital Statistics Reports, supra note 103, at 21.

105. Saul, supra note 4.

106. National Vital Statistics Report, supra note 103, at 21.

107. Saul, supra note 4.

108. March of Dimes Study, http://www.marchofdimes.com/professionals/14332_4545.asp (last visited Oct. 22, 2010).

109. $I d$.

110. $I d$.

111. Saul, supra note 4; National Vital Statistics Reports, supra note 103, at 18.

112. United Nations Department of Economic \& Social Affairs, Population Division, World 
made reducing this rate a national priority. In addition to the humanitarian incentives for reducing the rate of premature delivery, there are very real economic incentives for reaching the same end because caring for premature infants born as a result of in vitro fertilization alone costs an estimated $\$ 1$ billion. These are "expenses that eventually get passed along through the system and on to businesses and the consumer."113

Caring for twins born as a result of fertility treatments could be more expensive, financially and emotionally, than caring for naturally occurring twins. ${ }^{114}$ A recent study published in the Journal of Human Reproduction, a leading publication in Europe, found that twins born as a result of assisted reproductive therapy (ART) were significantly more likely to die within a month of birth, spent on average four more days in the hospital and suffered from longer term health problems more often than naturally occurring twins. ${ }^{115}$

The same journal published the results of study in 2008 indicating that singletons born as a result of ARTs were "more likely to suffer from twice the risk of some types of heart defects, more than twice the risk of cleft lip with or without cleft palate and over four times the risk of certain gastrointestinal defects compared with babies conceived without fertility treatments." 116 However, the study noted that the absolute risk of any birth defect remained very low. ${ }^{117}$ The study also observed that children born of ART induced multiple pregnancies suffered no increased risk of birth defects. ${ }^{118}$

\section{Medical Community's Response}

The totality of these side effects is such that the issue is not whether action ought to be taken to limit the number of multiples (high order or otherwise) born each year but rather by whom the action should or may be taken. In response to these side effects, the medical community implemented its own regulations and procedures designed to reduce the occurrence of

Population Prospectus the 2006 Revision: Highlights (2007), http://www.un.org/esa/population/ publications/wpp2006/WPP2006_Highlights_rev.pdf.

113. Saul, supra note 4.

114. Michèle Hansen et al., Twins Born Following Assisted Reproductive Technology: Perinatal Outcome \& Admission to Hospital, 24 OXFord J. Hum. ReProd. 2321-31 (2009).

115. $I d$.

116. Centers for Disease Control and Prevention, Press Release, National Birth Defects Prevention Study Shows Assisted Reproductive Technology is Associated with an Increased Risk of Certain Birth Defects (Nov. 17, 2008), http://www.cdc.gov/media/pressrel/2008/r081117.htm.

117. Centers for Disease Control, supra note 116.

118. Id. 
multiples. ${ }^{119}$ These measures include counseling at the start of fertility treatment, placing limits on the number of embryos transferred during IVF (currently, three at most), setting limits on when a woman may be given hormonal therapy and on how many egg follicles should be permitted to develop as a result. ${ }^{120}$ Given the dramatic decrease in the incidents of high order multiples in recent years, it appears these guidelines achieved their desired effect. ${ }^{121}$

\section{Assessment of Legislative Restrictions on Fertility TREatMents}

\section{A. Introduction}

In order to capitalize upon the success of the medical community in limiting high order births, the state and federal governments should expand the limitations placed by the medical community on the number of viable embryos a mother may carry. To achieve this, state and federal governments should mandate selective reduction, eliminate the use of hormone-based fertility treatments, codify the medical community's own standards, or take a more radical approach: change existing insurance laws.

Any measure must survive at the very least Casey's undue burden test ${ }^{122}$ because each solution touches on the right of a couple to beget children. Measures mandating selective termination and eliminating hormone-based fertility treatments would likely fail that test while codification of existing medical community standards and changes in insurance laws would likely pass. Alternatively, a measure may be subject to the higher strict scrutiny test under a Skinner analysis. ${ }^{123}$ The results of this analysis would be the same with measures mandating selective termination and eliminating hormonebased fertility treatments failing the test and codification of existing medical community standards and changes in insurance laws passing it.

119. Saul, supra note 4.

120. Telephone Interview with Melanie M. Ochalski, MD, supra note 61; NATional Vital STATISTICS REPORTS, supra note 103, at 20-21.

121. National Vital Statistics Reports, supra note 103, at 20-21.

122. Casey, 505 U.S. at 875.

123. Skinner, 316 U.S. at 541. 


\section{B. Possible Legislative Actions}

\section{Mandated Abortions}

The first 'option' can be dismissed out of hand. Constitutional and public policy arguments aside, practically speaking no state or federal representative endorsing such a law or regulation would be employed for long. Considering both Constitutional and public policy arguments, mandated selective termination violates a host of constitutional rights, privacy among them. From a policy standpoint, the United States has never intruded into the private lives of its citizens so deeply, and, frankly, it never should.

\section{Elimination or Sever Restriction of Access of Hormone-Based Fertility Treatments}

Although others have argued that the elimination or near elimination of hormone-based fertility treatments would be a viable and constitutional option, ${ }^{124}$ recent changes to both the data regarding children born of hormonebased ARTs ${ }^{125}$ and the rates of multiple births (high order or otherwise) ${ }^{126}$ undermine the justifications for such a dramatic measure. Even without these developments, restrictions on access to hormone-based fertility treatments would be largely unconstitutional under either Casey's undue burden test ${ }^{127}$ or under an Equal Protection Clause strict scrutiny analysis. ${ }^{128}$

ARTs are very different than other forms of medical treatment because of their ultimate goals: infertility and the creation of a human being. Treating ARTs and their regulation as if they are no different than blood pressure medication is a mischaracterization and diminution of the ultimate issues involved. ARTs implicate reproductive rights, which the Supreme Court has recognized as a fundamental right, ${ }^{129}$ let alone a fundamental interest. ${ }^{130}$ As such, any regulation of ARTs must survive Casey's tweaking of strict scrutiny. ${ }^{131}$

124. Lars Noah, Assisted Reproductive Technologies \& the Pitfalls of Unregulated Biomeidcal Innovation, 55 FlA. L. REV. 603, 664 (2003).

125. Id. at 613-14.

126. National Vital Statistics Reports, supra note 103, at 107-08.

127. Casey, 505 U.S. at 895.

128. Skinner, 316 U.S. at 541.

129. Griswold, 381 U.S. at $485-86$.

130. Skinner, 316 U.S. at 541.

131. Casey, 505 U.S. at 895. 


\section{Substantive Due Process Based Claims}

Although the majority of Americans appear willing to have greater government control in ARTs, as the Court in Casey observed was true of restricting access to abortions, the constitutionality of placing significant limits on access is questionable. The public is troubled by high-order multiples and by the short and long-term complications many of these children suffer. However, given the number of Americans who seek to use ARTs each year, the public would likely be unwilling to accept either a ban or severe restrictions on access to selected ARTs.

Restricting or eliminating access to hormone-based ARTs fails Casey's undue burden test ${ }^{132}$ for a number of reasons. First, scaling back access places an undue burden on a couple seeking to have a child because some women can conceive only through hormone-based ARTs. ${ }^{133}$ If an approved medication does not work but a non-approved one would, the woman will not be able to have a child. These procedures are also a necessary first step in the in vitro processes. ${ }^{134}$ Eliminating or severely restricting access to hormone-based therapies would therefore eliminate or restrict access to 'non-hormone' based ARTs as well. These roadblocks amount to placing a substantial obstacle in the path of a couple seeking to have a child.

Beyond placing an undue biological burden on certain couples, restricting or eliminating access to hormone-based ARTs would place an undue financial burden on many more couples. The in vitro process costs upwards of $\$ 12,000$ per cycle. ${ }^{135}$ The average couple requires four cycles in order to achieve pregnancy and few insurance companies are willing to cover the process. For couples who lack coverage, the hormone-based ARTs are a viable financial option, and are often their only one.

Any measure seeking to limit or eliminate access must sufficiently address this issue in order to be valid under Casey, ${ }^{136}$ even though socio-economic class is not recognized as a protected class. The actual issue in this case is not the financial classification of the couple but rather whether a government action has the purpose or effect of placing a substantial obstacle

132. Id. note 66 .

133. Am. Soc'y for Reprod. Med., Assisted Reproductive Technologies: A Guide for Patients, supra

134. $I d$.

135. $I d$.

136. Casey, 505 U.S. at 895. 
in the path of a couple seeking to have a child. Pretending otherwise is a gross mischaracterization of the issue.

\section{Equal Protection Clause Based Claims}

These measures would face similar challenges under the Equal Protection Clause's strict scrutiny test. If the Court follows Skinner ${ }^{137}$ because of the factual similarities between that case's sterilization of certain convicts and restricting/eliminating access to certain infertile couples, then the government action must pass a higher standard than the undue burden test laid out in Casey $^{138}$ to be valid.

Government interest would have to be legitimate and compelling, narrowly tailored, and the least intrusive means available. ${ }^{139}$ In the realm of ARTs, the legitimacy of the government interest is questionable because there is insufficient proof that governmental intervention is needed and because the relationship between that interest and the measures implemented in its name would be so extreme as to be irrational. Eliminating or restricting access to hormone-based ARTs in order to reduce the number of children born who suffer long-term health problems incurred as a result of a multiple pregnancy would be analogous to eliminating or restricting access to fast food in order to reduce the number of Americans who suffer long-term health problems incurred as a result of obesity.

Children suffer serious health problems regardless of whether they are born as a result of ARTs. If the government may constitutionally justify eliminating a method of procreation on the basis of possible adverse health effects in some cases where ARTs are used, the government rides a slippery slope toward justifying limiting the ability of couples that may have children with long-term health problems from having children. The justifications for each limitation would be the same - a government concern for the long-term health of children. The difference would be the method of producing those children.

The otherwise compelling nature of the government interest is also weakened by the successful reductions in multiple births (high order or otherwise) the medical community guidelines have accomplished. Given that the incidence of such births (and with them their side-effects) is on the

137. Skinner, 316 U.S. at 541.

138. Casey, 505 U.S. at 895.

139. See Skinner, 316 U.S. at 542. 
decline, ${ }^{140}$ the ostensibly compelling nature of the government's interest is weakened.

The efficacy of those guidelines also calls into question whether restriction/elimination of access to hormone-based ARTs would be narrowly tailored and if such action would be the least restrictive means available. Given the success of the guidelines and that they operate without severely restricting/eliminating access to hormone-based ARTs, government action doing so would be both insufficiently narrow and not the least restrictive means available.

\section{Codification of Medical Community Standards}

Codification of existing medical community standards would be sufficiently narrow, and it would pass the rational basis and undue burden tests, but it could only go so far. These guidelines successfully reduced the incidents of multiple births since their inception. ${ }^{141}$ Codification of these standards would standardize such progress but would not necessarily capitalize upon it.

Codification of existing standards passes both the undue burden and strict scrutiny tests. If doctors are unwilling to go beyond the guidelines out of a concern derived from professional reputation and medical risks, then a couple seeking ARTs would not be presented with an undue burden on their quest by governmental regulations/statutes limiting their access to those ARTs of which the medical community approves. The couple would be unable to access the therapies with or without the governmental actions. Thus, the government places no additional and no undue burden upon them.

Several states have already codified these provisions but the efficacy of these measures remains uncertain. Further complicating the situation, codification would need to be performed in such a way as to ensure that when the medical community standards evolved, the law could evolve with it. Absent such fluidity, the government runs the risk of creating legal obligations to engage in medical practices that have been discredited.

140. National Vital Statistics Reports, supra note 103, at 1, 20.

141. Id. at 20. 


\section{Changes in Existing Insurance Laws}

Codification of these standards would be a good first step but it would only go so far. In order for the government to continue the success of the ASRM guidelines, it must change the existing insurance laws. Physicians and patients alike already prefer the use of in vitro fertilization to hormone-based methods, all other factors being equal. ${ }^{142}$ The doctor has greater control over the results of the process and thereby greater control over any possible risks. The patient has a more guaranteed result and is not exposed to the sort of side effects associated with hormone-based ARTs.

Patients and doctors, however, must consider factors other than the best course of treatment. They must also consider the patient's ability to pay. In vitro fertilization is expensive at between $\$ 12,000$ and $\$ 15,000$ a cycle. In those states that do mandate its coverage, it is covered only as a last resort. ${ }^{143}$ In contrast, hormone-based ARTs may cost as little as $\$ 200-\$ 300$ a cycle. Changing the incentives for choosing ARTs methods to favor the more expensive but generally less risky in vitro would lead many patients and doctors to choose in vitro first.

In order for any measure to have real efficacy, the statute or regulation must have two prongs. First, the measure would have to mandate coverage of fertility treatments. Without this change, couples lacking coverage and lacking significant amounts of disposable income would turn first to hormone-based ARTs. Second, the measure must mandate that in vitro and its progeny should be covered as a first option and not as a last resort.

The change in coverage does not necessarily entail that all forms of ARTs cost the patient the same amount. The changes simply mean that the out of pocket expenses decrease and in vitro would be given a first option status, which in turn would likely lead to a decrease in the use of hormone-based ARTs. If these two prongs were established, the likelihood of high-order multiples would decrease precipitously.

142. Telephone Interview with Melanie M. Ochalski, MD, supra note 61.

143. Ark. Code Ann. $\S$ 23-85-137, 23-86-118 (2009); Cal. Health \& Safety Code $\S 1374.55$ (2009); 1989 Conn. Acts 05-196; Haw. Rev. Stat. §§ 431-IOA-1 16.5, 432.1-604 (2010); 215 ILl. Comp. Stat. 5/356, 125/5-3 (2010); Md. Code AnN., Ins. § 15-810 (2010), Health-Gen. § 19-706 (2010); Mont. Code Ann. §§ 33-22-1521, 33-31-102 (2009). 


\section{CONCLUSION}

Of the four possible government responses to the risks recreated by multiple pregnancies produced as a result of ARTs examined in this paper, only two can withstand Casey's undue burden test and/or strict scrutiny under an Equal Protection claim. Taken either separately or together, codification of existing medical community standards and changes in insurance laws that favor the use of in vitro fertilization over hormone-based ARTs manage to withstand constitutional challenges and would likely produced the desired results. 